\title{
PENINGKATAN KEDISIPLINAN DAN KETERAMPILAN BERPIKIR KRITIS MELALUI PENDEKATAN KONTEKSTUAL
}

\author{
ARMI YUSTINA, MARIA MELANI IKA SUSANTI, MARIA INDARTI RUSTAMTI \\ Universitas Sanata Dharma \\ e-mail: armiyustina94@gmail.com
}

\begin{abstract}
ABSTRAK
Pembelajaran jarak jauh masa pandemi covid-19 berdampak pada proses pembelajaran siswa seperti rendahnya kedisiplinan dan kemampuan berpikir kritis siswa. Tujuan penelitian ini adalah untuk (1) mendiskripsikan upaya peningkatan kedisiplinan dan kemampuan berpikir kritis siswa; (2) meningkatkan kedisiplinan siswa; dan (3) meningkatkan kemampuan berpikir kritis siswa pada mata pelajaran Bahasa Indonesia kelas III SD Kanisius Kalasan melalui pendekatan kontekstual. Penelitian tindakan kelas ini terdiri dari 4 tahapan yaitu perencanaan, pelaksanaan, pengamatan, dan refleksi. Subyek dalam penelitian adalah 52 siswa kelas III. Teknik dalam pengumpulan data adalah non-tes berupa wawancara, observasi dan kuesioner. Hasil penelitian menunjukkan: (1) pendekatan kontekstual dapat meningkatkan kedisiplinan dan kemampuan berpikir kritis siswa kelas III SD Kanisius Kalasan dengan menerapkan 7 komponen utama yaitu: konstruktivisme (constructivism), bertanya (questioning), menemukan (inquiry), masyarakat belajar (learning community), pemodelan (modeling), refleksi (reflection) dan penilaian sebenarnya (authentic assessment), (2) Penggunaan pendekatan kontekstual dapat meningkatkan kedisiplinan siswa dari kondisi awal sebesar 67, meningkat pada siklus I menjadi 78 dan pada siklus II menjadi 84, (3) Penggunaan pendekatan kontekstual dapat meningkatkan kemampuan berpikir kritis siswa kelas III dari kondisi awal 70, meningkat pada siklus I menjadi 79 dan menjadi 86 pada siklus II.
\end{abstract}

Kata Kunci : Model Pembelajaran, Berpikir Kritis, Pendekatan Kontekstual

\section{PENDAHULUAN}

Masyarakat Indonesia menyadari pentingnya pendidikan dalam kehidupan, ditandai dengan orang tua yang menyekolahkan anak mereka dari PAUD sampai tingkat perkuliahan. Menurut Hadiyanti (2008) sekolah merupakan ruang lingkup pendidikan yang di dalamnya terdapat proses mendidik, mengajar dan melatih sehingga perlu menjamin terselenggaranya proses pendidikan yang baik. Namun saat ini pembelajaran di sekolah tidak dapat dilaksanakan sebagaimana mestinya karena adanya virus covid-19.

Berdasarkan surat edaran MENDIKBUD No. 4 Tahun 2020 tentang pelaksanaan kebijakan pendidikan dalam masa darurat penyebaran corona virus disease (covid-19), pemerintah membatasi aktivitas masyarakat/social distancing, dengan menutup sekolah dan melakukan pembelajaran jarak jauh/dari rumah. Prinsip kebijakan pendidikan pada masa pandemi Covid-19 yang digunakan adalah "kesehatan lahir dan batin siswa, guru, tenaga kependidikan, keluarga, dan masyarakat merupakan pertimbangan utama dalam menetapkan kebijakan pembelajaran". Pembelajaran jarak jauh dilakukan di semua sekolah termasuk di SD Kanisius Kalasan.

Peneliti melakukan wawancara secara langsung dengan salah satu wali kelas pada tanggal 12 November 2020 di SD Kanisius Kalasan. Berdasarkan wawancara tersebut pembelajaran jarak jauh (PJJ) memiliki dampak positif dan negatif untuk guru dan siswa. Dampak positif dari PJJ adalah guru dituntut untuk "Melek" teknologi, menyampaikan materi menggunakan PPT, membuat dan mengedit video pembelajaran, mengupload ke youtube channel, menerapkan aplikasi online untuk pembelajaran seperti google meet atau zoom. Dampak positif bagi siswa adalah membuat anak lebih ahli dalam mengoperasikan kemajuan teknologi (HP, laptop, WA, Google meet, zoom dll), siswa dapat fleksibel dalam mengakses informasi kapan saja dan dimana saja, tetapi dengan pendampingan dari orang tua. 
Di lain sisi dampak negatif dari PJJ yang dirasakan oleh guru seperti penyampaian materi tidak maksimal, materi yang biasanya dapat disampaikan dalam 1 hari hanya dapat disampaikan selama 10 menit melalui video pembelajaran, interaksi guru dengan siswa kurang optimal. PJJ membuat motivasi dan semangat siswa berkurang terbukti dari tugas yang dikumpulkan melebihi batas waktu yang ditentukan oleh guru dan mengumulkan seadanya. Hal ini berdampak pada kedisiplinan dan kemampuan berpikir anak berkurang/tidak optimal. Padahal kedisiplinan merupakan salah satu pendidikan karakter yang harus diajarkan sejak dini.

Menurut Rini (2015) manfaat kedisiplinan adalah membuat siswa menjadi lebih tertib dan teratur dalam menjalankan kehidupannya, kehidupan menjadi aman dan mencegah hidup sembarangan, menghargai kepentingan orang lain, membiasakan hidup tertib di sekolah maupun di lingkungan sekitar. Selain memiliki karakter disiplin, siswa dilatih memiliki kemampuan berpikir kritis untuk menjawab tantangan abad 21. Menurut Razak (2017) berpikir kritis adalah sebuah pemikiran yang genting dimana memerlukan pemahaman yang tinggi, logis dan penganalisaan yang tajam dan dibutuhkan oleh siswa di abad 21 ini agar siswa dapat mengolah informasi secara rasional, logis, dan benar. Ada banyak pendekatan yang dapat digunakan untuk meningkatkan kedisiplinan dan kemampuan berpikir kritis siswa seperti pendektan kkontekstual. Rusman (2010) menyatakan bahwa pembelajaran kontekstual memberikan fasilitas kegiatan belajar siswa untuk mencari, mengolah, dan menemukan pengalaman belajar yang lebih bersifat konkret (terkait dengan kehidupan nyata) melalui keterlibatan aktivitas siswa dalam mencoba, melakukan, dan mengalami sendiri. Hal ini sejalan dengan kemampuan siswa dalam mengolah pengetahuan yang diperoleh dari kehidupan nyata.

UU No 20 tahun 2003 tentang Sistem Pendidikan Nasional dijabarkan salah satu fungsi pendidikan nasional adalah mengembangkan kemampuan dan membentuk watak. Salah satu pembentukan watak yang dapat ditanamkan kepada siswa adalah kedisiplinan. Kedisiplinan berasal dari kata dasar disiplin. Dalam KBBI kata "disiplin" artinya ketaatan atau kepatuhan terhadap tata tertib dan peraturan yang berlaku. Menurut Depdiknas (2006) menjabarkan disiplin adalah "Tingkat konsistensi dan konsekuen seseorang terhadap suatu komitmen atau kesepakatan bersama yang berhubungan dengan tujuan yang akan dicapai waktu dan proses pelaksanaan suatu kegiatan". Sedangkan Hadianti (2008) menjelaskan bahwa disiplin merupakan suatu sikap moral siswa yang terbentuk melalui proses dari serangkaian perilaku yang menunjukkan nilai-nilai ketaatan, kepatuhan, keteraturan, dan ketertiban berdasarkan acuan nilai moral.

Berdasarkan pendapat tersebut dapat disimpulkan bahwa kedisiplinan adalah sikap perilaku siswa yang menunjukkan nilai ketaatan, kepatuhan, dan komitmen terhadap tata tertib/peraturan yang berlaku untuk mencapai tujuan yang diinginkan. Kedisiplinan anak dapat dinilai dengan beberapa indikator yang ditunjukan melalui perilaku siswa, seperti: 1) datang tepat waktu, 2) menaati peraturan yang berlaku dan tertib, 3) berdoa sebelum pembelajaran, 4) menyelesaikan tugas tepat waktu. Indikator yang digunakan dalam penelitian ini disesuaikan dengan kondisi saat penelitian, dimana pembelajaran dilakukan dengan online menggunakan aplikasi zoom.

Selain kedisiplinan sebagai pendidikan karakter, kemampuan berpikir kritis juga perlu diajarkan kepada siswa. Simanjuntak (2019) menyatakan kemampuan berpikir kritis adalah kemampuan untuk berpikir secara logis, reflektif, sistematis, dan produktif yang diaplikasikan dalam membuat pertimbangan dan mengambil keputusan yang baik. Menurut Zubaidah (2018) keterampilan berpikir kritis penting dimiliki oleh siswa dalam menemukan sumber masalah dan bagaimana mencari dan menemukan solusi yang tepat atas masalah yang dihadapi. Kemampuan berpikir kritis ini perlu dikembangkan dan dilatih melalui proses pendidikan dengan pemilihan strategi pembelajaran yang benar.

Berdasarkan pendapat tersebut dapat disimpulkan bahwa kemampuan berpikir kritis adalah kemampuan untuk berpikir secara logis, rasional, sistematis, dan teliti melalui penalaran, pengamatan, observasi, maupun refleksi. Beberapa indikator kemampuan berpikir kritis adalah: 1) menjawab pertanyaan berdasarkan fakta, 2) membuat pertanyaan berserta jawabannya, 3) 
memberikan contoh, 4) membuat kesimpulan, dan 5) merefleksikan kegiatan. Siswa dapat lebih mudah berpikir kritis jika materi yang diajarkan sesuai dengan kenyataan. Materi yang selama ini diajarkan di sekolah berkaitan langsung dan bermanfaat dalam kehidupan sehari-hari, pendekatan pembelajaran yang sesuai dengan konteks materi untuk mempermudah siswa memahami. Menurut Depdiknas (2003) Pendekatan kontekstual merupakan konsep belajar yang membantu guru mengaitkan antara materi yang diajarkannya dengan situasi dunia nyata siswa dan mendorong siswa membuat hubungan antara pengetahuan yang dimilikinya dengan penerapannya dalam kehidupan mereka. Hal ini sejalan dengan pendapat Johnson (dalam Shanti: 2018) pendekatan kontekstual merupakan suatu proses pembelajaran yang melibatkan siswa dalam aktivitas penting yang membantu mereka mengaitkan pelajaran akademis dengan konteks kehidupan nyata yang mereka hadapi.

Pendekatan kontekstual adalah proses pembelajaran yang mengkaitkan materi dengan konteks kehidupan nyata sehingga, siswa dapat membuat hubungan antara materi yang dimiliki dan penerapanya dalam kehiduan nyata. Siswa lebih mudah memahami materi karena berkaiatan langsung dengan kehidupan mereka, pendekatan kontekstual mengutamakan pengetahuan dan pengalaman dalam dunia nyata. Rusman (2010) menyatakan bahwa pembelajaran kontekstual memberikan fasilitas kegiatan belajar siswa untuk mencari, mengolah, dan menemukan pengalaman belajar yang lebih bersifat konkret (terkait dengan kehidupan nyata) melalui keterlibatan aktivitas siswa dalam mencoba, melakukan, dan mengalami sendiri.

Pendekatan kontekstual menjadi lebih bermakna karena siswa berperan aktif dalam pembelajaran kemudian mengkaitkanya dengan kehidupan sehari-hari. Menurut Depdiknas (2003) Pembelajaran Konstektual adalah konsep belajar yang membantu guru mengaitkan antara materi yang diajarkannya dengan situasi dunia nyata siswa dan mendorong siswa membuat hubungan antara pengetahuan yang dimilikinya dengan penerapannya dalam kehidupan mereka sehari-hari, dengan melibatkan tujuh komponen utama pembelajaran efektif, yakni: konstruktivisme (constructivism), bertanya (questioning), menemukan (inquiry), masyarakat belajar (learning community), pemodelan (modeling), refleksi (reflection) dan penilaian sebenarnya (authentic assessment).

\section{METODE PENELITIAN}

Jenis penelitian yang digunakan dalam penelitian ini adalah penelitian tindakan kelas (PTK). Menurut Daryono (2014), Penelitian Tindakan Kelas adalah penelitian yang dilakukan guru kelas melalui kegiatan refleksi dengan tujuan memperbaiki kualitas pembelajaran di kelas, sehingga prestasi belajar siswa dapat meningkat. Dalam desain penelitian tindakan kelas menggunakan model Kurt Lewin (1992) yang terdiri dari 4 langkah saling berhubungan yaitu: perencanaan, pelaksanaan, pengamatan dan refleksi. Penelitian dilakukan dalam 2 siklus, setiap siklus terdiri dari 2 pertemuan, jumlah pembelajaran dalam penelitian ada 4 pertemuan. Penelitian ini dilakukan di SD Kanisius Kalasan dengan subyek penelitian siswa kelas III, berjumlah 56 siswa. Obyek yang diteliti adalah peningkatan kedisiplinan dan kemampuan berpikir kritis pada mata pelajaran Bahasa Indonesia melalui kontekstual.

Teknik pengumpulan data dalam penelitian ini berupa nontes dan tes. Dalam penelitian ini peneliti pengukuran kedisiplinan dan kemampuan berpikir kritis dengan menggunakan nontes berupa wawancara dengan guru kelas, observasi saat proses pembelajaran dan kuesioner yang diberikan kepada siswa. Sedangkan tes yang digunakan berupa tes uraian yang dikerjakan oleh siswa kemudian dikumpulkan sesuai waktu yang ditentukan untuk mengukur salah satu indikator kedisiplinan dan kemampuan berpikir kritis siswa. Teknik analisis data dalam penelitian ini menggunakan diskriptif kuantitatif. Analisis diskriptif digunakan untuk menggambarkan hasil yang didapatkan, mengenai rata-rata dan perbedaan hasil yang diperoleh untuk kedisiplinan siswa maupun kemampuan berpikir kritis. 
Penelitian dilakukan dalam 2 kali siklus, setiap siklus terdiri dari 2 kali pertemuan. Dalam setiap pertemuan menggunakan langkah-langkah PTK dari model Kurt Lewin (1992) yaitu: perencanaan, pelaksanaan, pengamatan dan refleksi yaitu: perencanaan, pelaksanaan, pengamatan dan refleksi. Sebelum melakukan penelitian peneliti menyiapkan beberapa kesiapan seperti: menyiapkan perangkat pembelajaran (RPP, soal evaluasi, perangkat penilaian dan media pembelajaran), lembar wawancara, lembar observasi dan lembar kuesioner.

\section{HASIL}

Berdasarkan hasil penelitian menggunakan pendekatan kontekstual data penelitian didapatkan dari hasil observasi saat pembelajaran dan kuesioner yang diisi oleh siswa. Hasil rata-rata dapat dilihat pada tabel dibawah ini:

Tabel 1 Nilai Rata-Rata Kedisiplinan dan Kemampuan Berpikir Kritis

\begin{tabular}{|l|c|c|c|c|}
\hline \multirow{2}{*}{ No } & \multirow{2}{*}{ Variabel } & \multirow{2}{*}{ Siklus } & \multicolumn{2}{|c|}{ Nilai } \\
\cline { 3 - 5 } & & & Observasi & Kuesioner \\
\hline 1 & \multirow{2}{*}{ Kedisiplinan } & Data Awal & 64 & 70 \\
\cline { 3 - 5 } & & Siklus I & 74 & 82 \\
\cline { 3 - 5 } & & Siklus II & 82 & 86 \\
\hline 2 & \multirow{2}{*}{$\begin{array}{l}\text { Kemampuan } \\
\text { berpikir kritis }\end{array}$} & Data Awal & 69 & 70 \\
\cline { 3 - 5 } & & Siklus I & 79 & 79 \\
\cline { 3 - 5 } & & Siklus II & 88 & 86 \\
\hline
\end{tabular}

Berdasarkan tabel di atas, hasil observasi dan kuesioner yang telah dilakukan menunjukkan adanya peningkatan nilai rata-rata kedisiplinan dan kemampuan berpikir kritis siswa setelah menggunakan pendekatan kontekstual. Pada hasil observasi kedisiplinan siswa kondisi awal diperoleh nilai rata-rata kelas sebesar 64, meningkat menjadi 74 pada siklus I dan meningkat kembali menjadi 82 pada siklus II. Untuk lembar kuesioner kedisiplinan siswa kondisi awal diperoleh nilai rata-rata kelas sebesar 70, meningkat menjadi 82 pada siklus I dan meningkat kembali menjadi 86 pada siklus II. Kenaikan nilai rata-rata siswa juga ditunjukkan pada kemampuan berpikir kritis dengan menggunakan kontekstual. Pada hasil observasi kemampuan berpikir kritis siswa diperoleh kondisi awal sebesar 69, meningkat menjadi 79 pada siklus I dan kembali meningkat menjadi 88 pada sikus II. Untuk lembar kuesioner diperoleh kondisi awal 70, meningkat menjadi 79 pada siklus I dan kembali mengalami peningkatan menjadi 86 pada siklus II. Agar dapat dilihat adanya peningkatan kedisplinan dan kemampuan berpikir kritis siswa, bisa dilihat pada diagram batang di bawah ini:

Peningkatan kedisiplinan dan kemampuan berpikir kritis siswa dengan menggunakan lembar observasi, memperhatikan indikator yang telah ditetapkan diantarannya, indikator kedisiplinan yaitu: 1) datang tepat waktu, 2) menaati peraturan saat pembelajaran, 3) menggunakan faasilitas zoom dengan baik, dan 4) mengumpulkan tugas tepat waktu. Sedangkan indikator kemampuan berpikir kritis yaitu: 1) menjawab pertanyaan berdasarkan fakta, 2) membuat pertanyaan beserta jawabanya, 3) memberikan contoh, 4) membuat kesimpulan, dan 5) merefleksikan kegiatan pembelajaran. Indikator yang digunakan dalam penelitian disesuaikan dengan keadaan saat penelitian karena menggunakan aplikasi zoom.

Hasil kueisoner yang diisi oleh siswa dengan menggunakan pendekatan kontekstual. Hasil kuesioner tersebut diperoleh dari jawab siswa, yang dinyatakan dalam "ya" atau "tidak" berikut beberapa pertanyaan kedisiplinan: 1) Saya masuk zoom tepat waktu, 2) Saya berdoa sebelum melakukan pembelajaran, 3) Saya mengikuti pembelajaran dengan tertib, 4) Saya mengumpulkan tugas tepat waktu. Pertanyaan mengenai kemampuan berpikir kritis: 1) Saya menjawab pertanyaan ketika guru bertanya, 2) Saya menjawab pertanyaan sesuai dengan isi bacaan, 3) Saya mampu menggunakan bahasa Indonesia yang baik dan benar, 4) Saya mengerjakan tugas dengan sungguh-sungguh, 5) Saya mampu memberikan contoh kegiatan mandiri, dan 6) Saya mampu merefleksikan pembelajaran hari ini. 
Dari hasil observasi dan kuesioner yang didapatkan pada penelitian dihitung nilai ratarata dengan memasukan rumus:

Nilai akhir kedisiplinan $=\frac{\text { Nilai observasi }+ \text { Nilai kuesioner }}{2}$

Nilai akhir kemampuan berpikir kritis $=\frac{\text { Nilai observasi }+ \text { Nilai kueisoner }}{2}$

Setelah memasukan nilai hasil observasi dan hasil kuesioner kedalam rumus didapatkan hasil sebagai berikut:

Tabel 2 Nilai Akhir Kedisiplinan dan Kemampuan Berpikir Kritis

\begin{tabular}{|l|l|c|c|c|}
\hline \multirow{2}{*}{ No } & \multirow{2}{*}{ Variabel } & \multicolumn{3}{|c|}{ Nilai Akhir } \\
\cline { 3 - 5 } & & Prasiklus & Siklus I & Siklus II \\
\hline 1 & Kedisiplinan & 67 & 78 & 84 \\
\hline 2 & $\begin{array}{l}\text { Kemampuan } \\
\text { berpikir kritis }\end{array}$ & 70 & 79 & 86 \\
\hline
\end{tabular}

Berdasarkan dari tabel di atas, diketahui bahwa adanya peningkatan kedisiplinan dan kemampuan berpikir kritis dengan menggunakan pendekatan kontekstual pada nilai akhir. Nilai akhir variabel kedisiplinan pada kondisi awal sebesar 67, setelah pembelajaran dilakukan dengan pendekatan kontekstual pada siswa kelas III tema 8 diperoleh nilai kedisiplinan sebesar 78 pada siklus I, dan meningkat kembali menjadi 84 pada siklus II. Variabel kemampuan berpikir kritis siswa mengalami peningkatan kondisi awal siswa diperoleh hasil sebesar 70, kemudian dilakukan penelitian menjadi 79 pada siklus I dan kembali mengalami peningkatan lagi menjadi 86 pada siklus II. Peningkatan kedisiplinan dan kemampuan berpikir kritis dapat dilihat pada diagram batang di bawah ini:

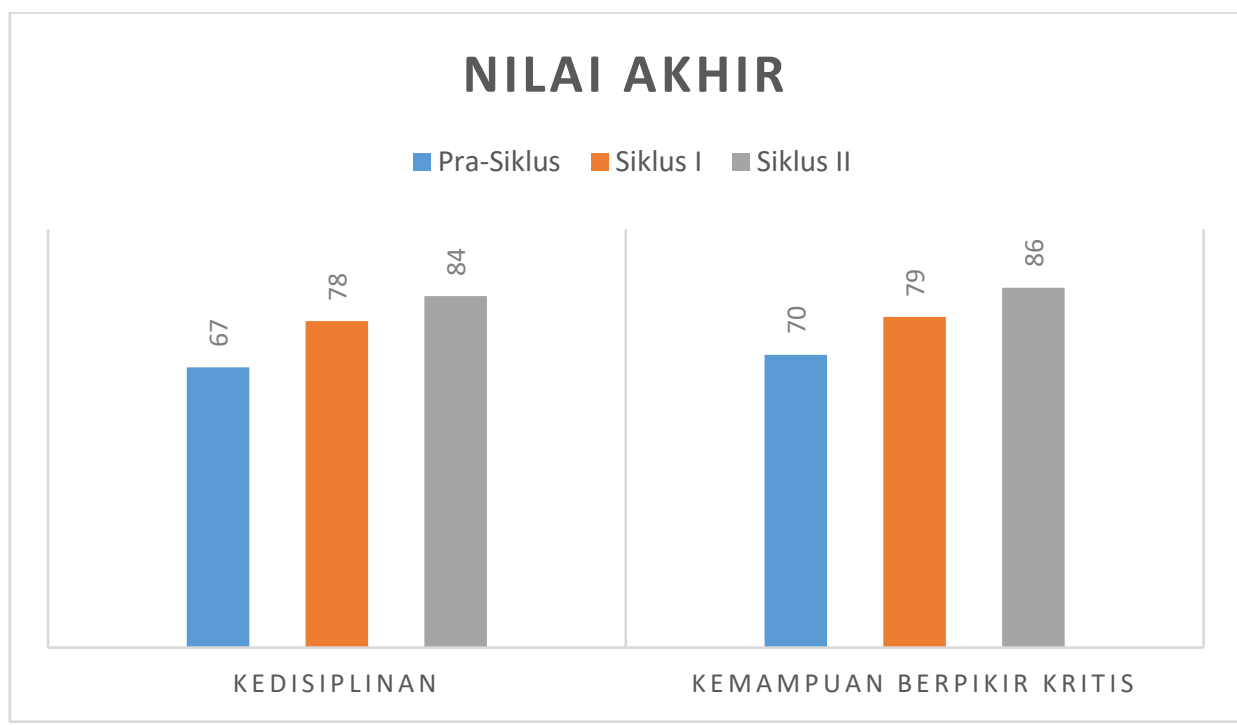

\section{Gambar 1. Diagram Peningkatan Kedisiplinan dan Kemampuan Berpikir Kritis}

Penggunakan pendekatan kontekstual dalam melakukan pembelajaran di sekolah dasar terutama kelas bawah (1-3 SD) memberikan pengaruh yang baik terhadap kedisiplinan dan kemampuan berpikir kritis siswa. Pembelajaran jarak jauh yang sekarang sedang dilakukan karena adanya masa pandemik membuat guru harus terus berpikir bagaimana agar siswa tetap bersungguh-sungguh dalam mengikuti pembelajaran mengumpulkan tugas. Peneliti mewajibkan siswa untuk melakukan presensi dan mengumpulkan tugas dengan batas waktu 
yang sudah ditetapkan. Pendekatan kontekstual menjadi lebih bermakna karena siswa berperan aktif dalam pembelajaran kemudian mengkaitkanya dengan kehidupan sehari-hari. Melalui pendekatan kontekstual siswa dibiasakan untuk berpikir secara mendalam dan kritis untuk mengkaitan ilmu yang diperoleh dan penerapanya. Siswa menyadari bahwa ilmu yang dipelajari berguna sebagai hidupnya nanti. Sehingga, membuat siswa memposisikan diri sebagai diri sendiri yang memerlukan suatu bekal yang bermanfaat untuk hidupnya nanti dan siswa berusaha untuk menggapainya.

\section{Pembahasan}

Penelitian dilakukan dalam 2 siklus, setiap siklus terdiri dari 2 kali pertemuan dengan alokasi waktu \pm 40 menit dengan menggunakan aplikasi zoom. Berdasarkan wawancara yang dilakukan oleh peneliti dengan guru kelas III terdapat beberapa kendala dalam melakukan pembelajaran dengan menggunakan pembelajaran zoom seperti pembelajaran berjalan kurang optimal dan bermakna karena siswa hanya mendengarkan penjelasan guru dan mengerjakan tugas yang diperintahkan guru tanpa contoh secara langsung. Upaya peningkatan kedisiplinan siswa dan kemampuan berpikir kritis siswa dalam penelitian ini menggunakan pendekatan Kontekstual.

Depdiknas (2003) menyebutkan pendekatan kontektual yang terdiri dari dari 7 kompenen utama yakni: konstruktivisme (constructivism), bertanya (questioning), menemukan (inquiry), masyarakat belajar (learning community), pemodelan (modeling), refleksi (reflection) dan penilaian sebenarnya (authentic assessment). Setiap siswa memiliki tingkat kedisiplinan yang berbeda-beda, kedisiplinan merupakan salah satu pendidikan karakter yang perlu diajarkan oleh siswa. Terdapat beberapa ahli yang menjelaskan arti kedisiplinan, dalam penelitian ini pengertian kedisiplinan adalah sikap perilaku siswa yang menunjukan nilai ketaatan, kepatuhan, dan komitmen terhadap tata tertib/peraturan yang berlaku untuk mencapai tujuan yang diinginkan. Menurut Rini (2015) manfaat kedisiplinan adalah membuat siswa menjadi lebih tertib dan teratur dalam menjalankan kehidupannya, kehidupan aman, dan teratur, mencegah hidup sembarangan, menghargai kepentingan orang lain, membiasakan hidup tertib di sekolah.

Sebelum melakukan pembelajaran peneliti memberikan beberapa tata tertib yang perlu dipatuhi oleh siswa diantaranya: (1) siswa masuk mengikuti zoom tepat waktu yaitu pukul 07.15 WIB, (2) siswa melakukan presensi dengan mengisi google form, (3) siswa mematikan microfon saat melakukan pembelajaran, (4) siswa menyebutkan nama ketika ingin bertanya/ menjawab pertanyaan dan (5) siswa mengumpulkan tugas tepat waktu. Dalam melatih kedisiplinan siswa diperlukan pembiasaan yang baik sehingga siswa terbiasa dalam melakukan tata tertib dalam kehidupan sehari-hari. Pembiasaan yang baik tersebut dapat diterapkan dengan pendekatan Kontekstual. Penerapan penedekatan Kontekstual berkaitan langsung dengan pengetahuan dan pengalaman siswa dalam kehidupan sehari-hari sehingga siswa dengan mudah melakukan tata tertib yang biasa dilakukan.

Ketika awal pembelajaran guru mengkaitan materi dengan pengetahuan/pemahaman siswa misalnya: kegiatan sehari-hari yang pernah di lakukan, tugas sehari-hari dirumah, ekstrakurikuler yang pernah dilakukan disekolah, seragam yang digunakan saat sekolah, dll. Setelah itu guru bertanya tentang kegiatan yang dilakukan tersebut, dengan begitu siswa dapat melakukan penalaran, berpikir dan pengamatan tentang kegiatan yang pernah dilakukan. Setelah melakukan penalaran siswa diberikan materi yang sesuai dengan KD (Kompetensi Dasar). Siswa dan guru dapat mengkaitkan materi yang didapatkan dengan kehidupan seharihari agar lebih mudah memahami materi. Setelah pembelajaran diselesaikan siswa melakukan refelksi mengenai kegiatan yang sudah dilakukan hari ini. Pada akhir pembelajaran guru memberikan penilaian dengan memberikan soal evaluasi. Pembuatan soal evaluasi memperhatikan indikator-indikator kemampuan berpikir kritis yang digunakan dalam peneltian ini. Siswa dapat lebih mudah memahami materi atau mampu berpikir kritis jika materi yang diberikan berkaitan dengan pengalaman dan pengetahuan langsung siswa. Berdasarkan hasil 
penelitian dan pembahasan dapat disimpulkan bawah penggunaan Kontekstual dapat meningkatkan kemampuan berpikir kritis siswa.

Hasimbuan (2014) pembelajaran kontekstual mengutamakan pada pengetahuan dan pengalaman atau dunia nyata, berfikir tingkat tinggi, berpusat pada siswa, siswa aktif, kritis, kreatif, memecahkan masalah, siswa bekajar menyenangkan, mengasyikkan, tidak membosankan, dan menggunakan berbagai sumber belajar. Peningkatan kedisiplinan dan kemampuan berpikir kritis siswa dengan menggunakan pendekatan kontekstual dapat merangsang siswa lebih mudah memahami materi pembelajaran. Saat melakukan penelitian, peneliti selalu mengkaitkan materi/ sub materi dengan kehidupan sehari-hari yang biasa didapatkan oleh siswa, seperti: tugas sehari-hari di rumah, kegiatan yang bila dilakukan secara mandiri, mengamati lingkungan sekitar dll. Hal ini dimaksudkan agar siswa lebih mudah memahami materi dan mempraktikanya dalam kehidupan sehari-hari.

\section{KESIMPULAN}

Berdasarkan hasil penelitian yang telah dilakukan dalan 2 siklus dengan menggunakan pendekatan kontekstual, peneliti dapat menyimpulkan bahwa:

1. Peningkatan kedisiplinan dan kemampuan berpikir kritis pada matapelajaran Bahasa Indonesia kelas III SD Kanisius Kalasan dapat meningkat dengan melalui pendekatan kontekstual seperti: konstruktivisme (constructivism), bertanya (questioning), menemukan (inquiry), masyarakat belajar (learning community), pemodelan (modeling), refleksi (reflection) dan penilaian sebenarnya (authentic assessment),

2. Penggunaan pendekatan kontekstual dapat meningkatkan kedisiplinan siswa kelas III SD Kanisius Kalasan dari kondisi awa sebesar 67, meningkat pada siklus I menjadi 78 dan kembali meningkat pada siklus II menjadi 84

3. Penggunaan pendekatan kontekstual dapat meningkatkan kemampuan berpikir kritis siswa kelas III SD Kanisius Kalasan dari kondisi awal 70, meningkat pada siklus I menjadi 79 dan kembali mengalami peningkatan menjadi 86 pada siklus II.

\section{DAFTAR PUSTAKA}

Dirjen Dikdasmen Depdiknas RI. (2003). UU No 20 Sistem Pendidikan Nasional. Jakarta: Ditjen Dikdasmen Depdiknas.

Dirjen Dikdasmen Depdiknas RI. (2003). Pendekatan Kontekstual (Contextual Teaching and Learning (CTL). Jakarta: Ditjen Dikdasmen Depdiknas.

Hadianti, L. S. (2017). Pengaruh Pelaksanaan tata tertib sekolah terhadap kedisiplinan belajar siswa (Penelitian deskriftif analisis di SDN Sukakarya II Kecamatan samarang Kabupaten Garut). Jurnal Pendidikan UNIGA, 2(1), 1-8. Diakses dari https://journal.uniga.ac.id/index.php/JP/article/view/11 pada tanggal 22 Januari 2021 pukul 12.00 WIB.

Hasibuan, M. (2018). Peningkatan kemampuan pemecahan masalah matematika melalui model pembelajaran contextual teaching and learning (ctl) pada pokok bahasan lingkaran siswa kelas VIII SMP N 2 Barumun Kabupaten Padang Lawas (Doctoral dissertation, IAIN Padangsidimpuan). Diakses dari http://etd.iain-padangsidimpuan.ac.id/3618/ pada tanggal 22 Januari 2021 pukul 12.15 WIB.

Razak, F. (2017). Hubungan kemampuan awal terhadap kemampuan berpikir kritis matematika pada siswa kelas VII SMP Pesantren IMMIM Putri Minasatene. Mosharafa: Jurnal Pendidikan Matematika, 6(1), 117-128. Diakses dari 
https://journal.institutpendidikan.ac.id/index.php/mosharafa/article/view/mv6n1_11 pada tanggal 20 April 2021 pukul 13.00 WIB

Rini, E. S. (2015). Pengaruh Perhatian Orang Tua dan Kedisiplinan Siswa terhadap Prestasi Belajar Mata Pelajaran IPS. Jurnal Penelitian dan Pendidikan IPS, 9(2). Diakses dari http://ejournal.unikama.ac.id/index.php/JPPI/article/view/1656 pada tanggal 20 April 2021 pada pukul $14.00 \mathrm{WIB}$

Shanti, W. N., Sholihah, D. A., \& Abdullah, A. A. (2018). Meningkatkan kemampuan berpikir kritis melalui ctl. Jurnal Pembelajaran Matematika, 5(1). Diakses dari https://jurnal.uns.ac.id/jpm/article/view/26034 pada tanggal 3 februari 2021 pukul 19.00 WIB

Simanjuntak, M. D. R. (2019). Membangun Ketrampilan 4C Siswa Dalam Menghadapi Revolusi Industri 4.0. Prosiding Seminar Nasional Fakultas Ilmu Sosial Universitas Negeri Medan Vol 3 Tahun 2019, hal 921 - 929. Diakses dari http://digilib.unimed.ac.id/37330/ pada tanggal

Zubaidah, S. (2018). Mengenal 4C: Learning and innovation skills untuk menghadapi era revolusi industri 4.0. In 2nd Science Education National Conference (Vol. 13).

Daryanto. (2014). Penelitian Tindakan Kelas Dan Penelitian Tindakan Sekolah. Yogyakarta: Gava Media 